Luis Jimena Quesada 가 https://orcid.org/0000-0003-4041-0576

University of Valencia, Spain

European Committee of Social Rights (former President)

\title{
RIGHTS OF YOUNG PEOPLE AND THE EUROPEAN SOCIAL CHARTER*
}

\begin{abstract}
The European Social Charter (alongside the case-law of the European Committee of Social Rights) forms the most striking binding legal source for young people's social rights, providing a framework for synergies with both the European Union and the Council of Europe's other instruments and mechanisms in this area. In the current times of pandemic, the most important thing is preventing the COVID-19 crisis (which has economic, political and social dimensions) from becoming a crisis of values among young people. From this perspective, on the one hand, the paper focuses on access of young people to education, labour market and housing. On the other hand, it proposes measures aimed at raising awareness of the Social Charter among young people and to capitalise on it in practice instead of insisting on drafting a specific European instrument on their rights. Finally, the author insists that all Council of Europe Member States should accept (if they have not yet done so) in the spirit of the "Turin process," the collective complaints procedure and the revised European Social Charter.
\end{abstract}

Słowa kluczowe: prawa młodych osób, Europejska Karta Społeczna, kryzys COVID-19

Keywords: young people's rights, European Social Charter, COVID-19 crisis

ASJC: 3308, JEL: K31

* This paper has its origin on the research done by the author for the Congress of Local and Regional Authorities of the Council of Europe [leading to its Resolution 442 (2019) and Recommendation 433 (2019) on Social Rights of Young People: The Role of Local and Regional Authorities] and has been updated in the framework of the Research Group "Human Rights and the European Social Charter" (University of Valencia, Spain, reference: GIUV2013-148). 


\section{Introduction: The key European legal instrument for young people's rights}

The European Social Charter (ESC or "Social Charter"), adopted in 1961 and revised in 1996 within the Council of Europe, is the fundamental European human rights treaty relating more specifically to young people. In particular, it explicitly refers to young people as being entitled to social rights in terms of education and labour market integration (vocational guidance and training, Art. 9 and 10) and benefits for the newly married (social, legal and economic protection for family life, Art. 16).

On the other hand, young people implicitly enjoy the other rights enshrined in the ESC (and in the case law of the European Committee of Social Rights-the ESCR or "the Committee" - in the context of the two monitoring mechanisms: reporting system and collective complaints procedure) in the areas of work (Art. 1), health (Art. 11), social security (Art. 12), social and medical assistance (Art. 13) and entitlement to social welfare services (Art. 14).

In addition, the Committee has addressed from the angle of the ESC situations of vulnerability affecting young people, including age discrimination in remuneration (Art. 4) and gender dimension (Art. 20), the status of young people with disabilities (Art. 15) and migrants (Art. 18 and 19), protection against poverty and social exclusion (Art. 30) and access to housing (Art. 31).

There are also aspects which, although not explicitly provided for in the Social Charter (including the 1961 text), were nevertheless discussed during the preparatory phase (travaux préparatoires) (for example, it was recommended that university education should be made gradually free and that a grant for students should be introduced), ${ }^{1}$ and continued to be discussed with a view to formal recognition in the text of the treaty (for example, proposal in 2003 for an Additional protocol to the revised Social Charter concerning the right to higher education).

In any case, the lack of provisions explicitly extending the material scope of the Social Charter has not undermined the conception of the treaty as a "living instrument" considering that higher education is already covered by Art. 10 of the Social Charter and that young people over 18 years of age should also be able (from the angle of Art. 13) to have access to a minimum income to be able to live independently: among others, Parliamentary Assembly Resolutions 1885 (2012). The Young Generation Sacrificed: Social, Economic and Political Implications of the Financial Crisis, and 2197 (2018), The Case for a Basic Citizenship Income (Bynner, Parsons 2002, p. 179). ${ }^{2}$

${ }^{1}$ Collected "travaux préparatoires" of the European Social Charter, Vol. 2 (1955), https://www.coe.int/ en/web/turin-european-social-charter/preparatory-work (access: 8 June 2020), pp. 28, 34.

${ }^{2}$ In Resolution 1885 (2012), the Assembly noted in particular that there are growing numbers of young people "not in employment, education or training" (so-called NEETs) who largely depend on family solidarity. However, as indicated in the report accompanying Resolution 2197 (2018), the European guaranteed minimum income schemes should help integrate such young people more fully into society, not least because this is a corollary obligation under Art. 13 and 14 of the Social Charter. 
In the case of these areas, where there has been particular insecurity in the context of the economic and financial crisis over the last decade (for example, the increase in youth unemployment or difficulties in accessing higher education because of the reduction in the number of student grants or the increase in university fees), restrictions are offset by the Social Charter as a binding legal instrument, and it is even more important to fight the current COVID-19 crisis.

\section{The Social Charter and its synergies within the European system for the protection of human rights}

\subsection{Synergies within the Council of Europe}

In consistency with the previous section, it is worth reminding that the recommendations of the Parliamentary Assembly of the Council of Europe on Young People's Access to Fundamental Rights [2015 (2013)] and Towards a European Framework Convention on Youth Rights [1978 (2011)], as well as the Committee of Ministers' Recommendation $\mathrm{CM} / \operatorname{Rec}(2016) 7$ on Young People's Access to Rights were occasions to underline that rather than adopting a specific treaty on the rights of young people, the aim should be to take measures in order to capitalise on the binding instruments, as enshrined in the European Convention on Human Rights (ECHR) and the revised Social Charter.

Indeed, the ECHR has a subsidiary nature in this field, since it does not explicitly set out rights and freedoms relating to young people. The case law of the European Court of Human Rights does include some cases submitted by young applicants which involved the protection of certain rights (civil and political and, indirectly, social). However, this case law remains very limited compared with the case law stemming from the broader personal and material scope of the Social Charter. It is therefore very difficult to derive from the Court's case law examples concerning access to social rights by young people. ${ }^{4}$

${ }^{3}$ Parliamentary Assembly Recommendation 1978 (2011) Towards a European Framework Convention on Youth Rights (adopted on 24 June 2018) served as an opportunity to confirm that it is not necessary to adopt a specific treaty on the rights of young people, but that we should instead capitalise on the binding instruments which already exist in the Organisation: its Principle 7.1 invites member states "to take measures to facilitate young people's access to fundamental rights as enshrined in the European Convention on Human Rights and the revised European Social Charter."

${ }^{4}$ See, for instance, selected case law of the European Court of Human Rights concerning young people aged 18 to 35 years published by the Research Division of the Court in 2012: Research Report. Selected Case-Law of the European Court of Human Rights on young people, Council of Europe/European Court of Human Rights, 2012, 26 pages (www.echr.coe.int, Case-law-Case-law Analysis-Research Reports). In particular, this selection presents a few dozen judgments of the Court (or decisions or reports of the former European Commission of Human Rights) concerning conscientious objection to military service, expulsion of second-generation migrants and forced labour (foreigners' rights are involved in many of these cases), a case concerning access to a professional career (from the angle of the protection of family life and the recognition of academic qualifications involving obstacles ratione materiae or falling within 
With this in mind, in Recommendation CM/Rec(2015) on the Access of Young People from Disadvantaged Neighbourhoods to Social Rights (O'Kelly, Muir 2016), the Committee of Ministers had referred explicitly to a large number of provisions of the 1996 revised Social Charter (Art. 1, 7, 9, 10, 11, 15, 17, 19, 21, 30, and 31) and called for "the relevant conclusions and decisions of the European Committee of Social Rights" to be taken into account. This recommendation stresses that access to certain social rights (quality education, secure employment, decent living conditions, adequate transport, health care, technology and opportunities for social, cultural and economic participation) "is a prerequisite for the inclusion and active citizenship of all young people."

The proposals made in this recommendation are incorporated, with a broader scope, in Recommendation CM/Rec(2016)7 of the Committee of Ministers to member states on Young People's Access to Rights (adopted on 28 September 2016), which also mentions the "decisions and conclusions of the European Committee of Social Rights and invites states which have not already done so to ratify the 1996 revised European Social Charter and the 1995 Protocol providing for a system of collective complaints." In the appendix to this recommendation, the Committee of Ministers also invites member states to "facilitate young people's access to social rights by strengthening the implementation of the European Social Charter's provisions."

In such recommendation, the Committee of Ministers refers to the already cited Parliamentary Assembly Recommendation 2015 (2013) on Young People's Access to Fundamental Rights (adopted on 24 April 2013), in which the Assembly welcomed the launch, in February 2013, of the Council of Europe campaign, "Nurturing Human Rights," with a "view to promoting rights and freedoms enshrined in the European Convention on Human Rights, with an emphasis on young people. It believes that the campaign should be further widened to also encompass the rights enshrined in the European Social Charter (revised)."

In addition to the flagship document of the Council of Europe on social rights (and the place of young people in this treaty), and complementing the work done by other bodies of the organisation (Parliamentary Assembly, Committee of Ministers, the Youth Sector, etc.), the Congress of Local and Regional Authorities has produced several texts on young people's access to their rights (in general and/or more specifically, social rights) from a local and regional governance point of view. ${ }^{5}$

a state's margin of discretion in terms of the exercise of a profession) and two cases relating to university studies (concerning the language of instruction for some courses and the wearing of religious symbols). The Court's subsequent case law provides interesting examples, inter alia, of young migrants who were victims of forced labour (Chowdury and Others v. Greece of 30 March 2017, violation of Art. $4 \$ 2$ ) and of young people with disabilities faced with physical barriers to access to university premises (Enver Şahin v. Turkey of 30 January 2018, violation of Art. 14 [non-discrimination] in conjunction with Art. 2 of Protocol No. 1 [right to education]), etc., but the impact of this case law is still limited with regard to implementation of young people's social rights at local and regional level.

${ }_{5}$ Among others, Resolution 296 (2010) on the Role of Local and Regional Authorities in the Implementation of Human Rights, Resolution 334 (2011) Developing Indicators to Raise Awareness of Human 


\subsection{Synergies with the European Union}

EU primary law (in particular, the Treaty on the Functioning of the EU, TFEU) addresses the social issues affecting young people from the angle of the labour market and "the exchange of young workers" (Art. 47 TFEU). Furthermore, in order to develop the European dimension in the fields of education, vocational training and sport, the EU's action involves "encouraging the development of youth exchanges and of exchanges of socio-educational instructors, and encouraging the participation of young people in democratic life in Europe" (Art. 165 TFEU), and aims to "facilitate access to vocational training and encourage mobility of instructors and trainees and particularly young people" (Art. 166 TFEU). In the area of EU external action, "in order to establish a framework for joint contributions from young Europeans to the humanitarian aid operations of the Union, a European Voluntary Humanitarian Aid Corps shall be set up" (Art. 214 TFEU). ${ }^{6}$

With regard to access by young people to social rights in soft-law instruments, the preamble to the European Pillar of Social Rights ${ }^{7}$ underlines the need to address economic and social insecurity with a view to the "provision of better opportunities for youth" ( $(7)$ in "a Union where young people receive the best education and training and can study and find jobs across the continent," given that "the social consequences of the crisis have been far-reaching - from youth and long-term unemployment to the risk of poverty-and addressing those consequences remains an urgent priority" (\$\$ 9-10). To deal with these consequences, Chapter I of the Pillar (Equal opportunities and access to the labour market) highlights "active support to employment," stating that "young people have the right to continued education, apprenticeship, traineeship or a job offer of good standing within 4 months of becoming unemployed or leaving education" ( $\$ 4 \mathrm{~b})$.

This chapter of the pillar actually reiterates the main thrusts of the Council Recommendation of 22 April 2013 on establishing a Youth Guarantee, which calls on member States to ensure that all young people aged under 25 receive a good-quality offer of employment, continued education, an apprenticeship or a traineeship within a period of four months of becoming unemployed or leaving formal education. The key

Rights at Local and Regional Level, Resolution 365 (2014) Best Practices of Implementation of Human Rights at Local and Regional Level in Member States of the Council of Europe and Other Countries, Resolution 414 (2017) Forever Young? The Role of Youth Policies and Youth Work at Local and Regional Levels in Supporting Young People's Transition to Autonomy and Working Life and Resolution 442 (2019) Social Rights of Young People: The Role of Local and Regional Authorities.

${ }^{6}$ In the case of the EU, reference should also be made to the European Solidarity Corps, which creates opportunities for young people to volunteer or work in projects in their own country or abroad that benefit communities and people around Europe. In the case of the Council of Europe, reference should be made to the European Convention on the Promotion of a Transnational Long-Term Voluntary Service for Young People (adopted on 11 May 2000).

7 See Interinstitutional Proclamation on the European Pillar of Social Rights by the European Parliament, Council and Commission (OJ C 2017/428, p. 10). 
challenge consists in ensuring the comprehensive and lasting implementation of the youth guarantee and extending its application to all young people. ${ }^{8}$

Alongside the above general provisions of EU primary law and soft law (pillar) relating to young people, reference should be made to the Youth Strategy agreed by EU ministers. ${ }^{9}$ The EU Youth Strategy is also supported by other complementary initiatives, including the Erasmus+ Programme. ${ }^{10}$ Of course, young people should not be seen as a homogeneous block. For instance, young people born in the information era are now frequently referred to as "digital natives" (Capitanescu Benetti, Connac 2020, p. 4). But there is still an urban-rural literacy gap, ${ }^{11}$ and young people who are economically and socially disadvantaged tend to be less digitally literate. ${ }^{12}$ To address this challenge, the European Commission adopted a Digital Education Action Plan in January 2018. ${ }^{13}$

\section{Rights of young people in the European Committee of Social Rights' case-law}

In the current times of pandemic, the most important thing is preventing the COVID-19 crisis (which has economic, political and social dimensions) from becoming a crisis of values among young people. ${ }^{14}$ From this perspective, the focus will be put on access of young people to education, labour market and housing.

With regard to the first issue, there are currently at least two main challenges: firstly, young people need help to complete upper secondary education so as to reduce the

${ }^{8}$ See Communication from the Commission of October 2016, The Youth Guarantee and Youth Employment Initiative Three Years on $\{\mathrm{COM}(2016) 646 \mathrm{final}\}$ and its Communication of December 2016, Investing in Europe's Youth $\{\mathrm{COM}(2016) 940$ final\}.

9 In May 2018, the European Commission presented proposals for a new EU Youth Strategy for the period from 2019-2027.

${ }^{10}$ Regulation (EU) No 1288/2013 of the European Parliament and of the Council of 11 December 2013 establishing 'Erasmus+': The Union programme for education, training, youth and sport.

${ }^{11}$ Enhancing Youth Political Participation throughout the Electoral Cycle: A Good Practice Guide, United Nations Development Programme, New York 2013, p. 13.

${ }_{12}$ European Commission, The International Computer and Information Literacy Study (ICILS): Main Findings and Implications for Education Policies in Europe, 2014.

${ }_{13}$ Commission staff working document on the Digital Education Action Plan $\{\mathrm{COM}(2018) 22$ final, Brussels $\}$, \{SWD(2018) 12 final, p. 10\}.

${ }^{14}$ ECSR, Statement of Interpretation on the Right to Protection of Health in Times of Pandemic (adopted by the Committee on 21 April 2020): "The Committee wishes to recall that many of the above measures are required to comply not only with the obligation to protect the right to protection of health under Article 11, but also with other Charter obligations related to health, including obligations in respect of ... the right of children and young persons to protection and health care (Article $7 \$ \$ 9-10$ and Article $17 \$ 1$ ). During a pandemic, States Parties must take all possible measures as referred to above in the shortest possible time, with the maximum use of available financial, technical and human resources, and by all appropriate means both national and international in character, including international assistance and cooperation." 
school drop-out rate; secondly, they need help to access higher education with grants or loans that can be repaid reasonably. Unfortunately, public expenditure and deficit reduction measures adopted in some countries in response to the economic crisis have led to increased university fees and the replacement of grants by loans at unreasonable interest rates. ${ }^{15}$ As a result, there is a real student debt problem in Europe and worldwide (Toca 2018).

In this connection, Art. 10 of Social Charter, as interpreted by the ECSR, covers the right to higher education with a very broad scope (e.g., the right to access to education and the right to financial assistance). That said, a concern for legal certainty led young people's representatives (in particular, AEGEE-Europe/European Students' Forum) to put forward a proposal in April 2002 to amend the Social Charter with a view to increasing the impact of Art. 10 through separate recognition of a right to higher education. ${ }^{16}$

The ECSR has also tackled specific situations of vulnerability. For example, in France it has been necessary to launch major programmes to promote the social inclusion of young people with autism. ${ }^{17}$ Similar good practices are also needed to combat other discriminatory stereotypes among young people (e.g. regarding sexual orientation, gender identity, gender expression and bodily diversity).

Undoubtedly, proper education at an early age is necessary to prevent these discriminatory stereotypes taking hold among children and teenagers. In this respect, it is worth mentioning the measure by the Croatian government to withdraw a biology textbook which took a discriminatory approach regarding sexual orientation, in response to a decision by the ECSR..$^{18}$ Nevertheless, education (formal or non-formal) is not enough on its own as a means of preventing and combating discriminatory stereotypes. From this point of view, the wide range of good practices in this area (emergency hotlines to protect women victims of gender-related offences, training for judges,

15 OECD, Education at a Glance 2017: OECD Indicators, OECD Publishing, Paris 2017, https://www. hm.ee/sites/default/files/eag2017_eng.pdf (access: 23 June 2020).

${ }^{16}$ The proposal was taken up by the Governmental Committee of the Social Charter, but in the end was not acted upon: Proposed Additional Protocol to the Revised European Social Charter Concerning the Right to Higher Education, Governmental Committee of the European Social Charter, Strasbourg, 30 July 2003 \{TS-SG(2003) 24\}.

17 Successive action plans covering the periods 2005-2007 ( $1^{\text {st }}$ Autism Plan), 2008-2010 ( $2^{\text {nd }}$ Autism Plan) 2013-2017 ( $3^{\text {rd }}$ Autism Plan) and 2018-2022 (4 $4^{\text {th }}$ Autism Plan). The content of these Autism Plans has been influenced substantially by the work of the Council of Europe: see the decisions of the ECSR of 4 November 2003 (Complaint No. 13/2002, International Association AutismEurope (IAAE) v. France) and of 11 September 2013 (Complaint No. 81/2012, Action européenne des handicapés (AEH) v. France). In particular, the ECSR considered in this last decision that the denial, in practice, of the right of children and adolescents with autism to continue attending school beyond compulsory school age despite the fact that this was the legal right of all pupils, amounted to a missed opportunity for the persons concerned to attain their potential in the mainstream school environment ( $\$ \$ 92-93)$.

${ }_{18}$ Decision on the merits, 30 March 2009 (Complaint No. 45/2007, INTERIGHTS v. Croatia, Art. 11 $\$ 2$ ESC). 
antidiscrimination institutions, etc. $)^{19}$ are of particular interest here and show the importance of ongoing non-sexist education (for the whole population) and training (for the relevant professionals). ${ }^{20}$ On the other hand, informal education in the broad sense includes the key role of the media in this area (Romer, Jamieson, Pasek 2009, p. 65).

Secondly, the ESCR was confronted with measures restricting the social and labour rights of young people enshrined in the Social Charter during the most sensitive period of the economic crisis (Stangos 2016, p. 86). More specifically, the first two decisions which directly addressed the issue of austerity and labour market flexibility measures (adopted under the influence of the Troika) that had a particular impact on young people were adopted by the ECSR on 23 May 2012.

In the first decision (Complaint No. 65/2011, GENOP-DEI v. Greece), the ECSR concluded that Art. $4 \$ 4$ of the Social Charter had been violated, as domestic legislation allowed dismissal without notice or compensation during the first twelve-month period for workers on open-ended contracts. In the second decision (Complaint No. 66/2011, GENOP-DEI and ADEDY v. Greece), the ECSR concluded that there had been a violation of various provisions of the Social Charter (Art. $7 \S 7,10 \S 2,12 \S 3$, and $4 \S 1$ ) after examining the restrictive provisions concerning annual leave, the training and apprenticeship systems for young people, the social security cover in "special apprenticeship contracts" between employers and young people aged 15 to 18 years and the provisions on extremely low pay (a small percentage of the national minimum wage) payable to workers aged under 25 , "which is below the poverty level" ( $\$ 65)$ and clearly discriminatory on the ground of age $(\$ \$ 68-70)$.

A more recent collective complaint (No. 150/2017, European Youth Forum v. Belgium) was registered on 11 May 2017 relating to Art. $4 \$ 1$ (right to a fair remuneration) and $7 \$ 5$ (right of children and young persons to protection) of the Social Charter. The complainant organization alleges that the provisions in Belgian law that enable unpaid internships, and the lack of enforcement of provisions that aim to curtail them, violate these articles. The ECSR declared the complaint admissible on 5 December 2017.

In this context, the economic crisis over the past decade (exacerbated by the COVID-19 crisis) has created insecurity for young people not only on an economic and social level (in terms of lack of employment opportunities) but also on a political and cultural level (in terms of influence in the employment sector) before the general and increasing virtualization of social relations (Sedda 2020, p. 117). In effect, there is a tendency to focus on the issue of young people's democratic participation (including the voting age), but the concern about the degree of political apathy among young people should

19 See Gender Equality Commission, Compilation of Good Practices on Women's Access to Justice, Council of Europe, 2015, 136 pages. See also the webpage on gender mainstreaming: https://www.coe. $\mathrm{int/en/web/genderequality/gender-mainstreaming} \mathrm{(access:} 23$ June 2020).

${ }^{20}$ See Gender Equality Commission, Compilation of Good Practices to Combat Sexism in Council of Europe Member States, Information Document (Revised 2), Strasbourg, 4 June 2018, 47 pages, https:// $\mathrm{rm}$.coe.int/compilation-of-good-practices-to-prevent-and-combat-sexism-revised/16808b15a5 (access: 23 June 2020). 
go hand in hand with measures to combat young people's passivity in the world of work (e.g. low level of trade union membership and of involvement in collective bargaining). ${ }^{21}$

This "industrial relations" apathy reflects a crisis of values alongside the economic crisis. In this same scenario, stereotypes concerning traditional roles go a long way to explaining the limited range of employment choices for women and the obstacles they face in their careers. On the one hand, good practices tackling sexual harassment at work, where most of the victims are young women, are needed. ${ }^{22}$ On the other hand, in terms of combating the gender wage gap (most significant in the case of young women finding their first jobs), progress has also been made in practice, ${ }^{23}$ as changes have occurred in legislation and case-law (some countries have brought their legislation into line with ECSR case law so as not to make pay comparisons within the same undertaking and enable pay comparisons between several companies). ${ }^{24}$

Thirdly, young people's difficulties in accessing housing are closely linked to changes affecting young people and their diverse nature, as their situation in relation to employment (and hence their economic opportunities and financial possibilities) varies depending on their levels of education and the regions where they live in each country. By way of example, France is one of the EU member states where young people move out of their parents' homes the earliest. However, it is also one of the countries where families provide most assistance with moving out, with not moving out probably being most closely related with job insecurity (Bugeja-Bloch 2013, p. 179).

Given this contrasting situation, the French authorities have altered the country's housing legislation, also in the light of the ECSR' case-law (e.g. decisions on the merits of 5 December 2007 on Complaint No. 33/2006, International Movement ATD-Fourth World v. France, and Complaint No. 39/2006, FEANTSA v. France), in particular with the definition of criteria for decent housing, the introduction of urgent measures to prevent evictions and the establishment of an enforceable right to housing (the "DALO Act," No. 2007-290 of 5 March 2007). With more specific regard to measures designed to foster access to housing by young people, greater flexibility has been introduced in the conditions relating to subletting to students and apprentices (Guichet 2013, p. 13).

${ }^{21} 15^{\text {th }}$ report by Estonia on the implementation of the ESC, 3 January 2018, RAP/RCha/EST/15(2018), pp. 39-41, https://rm.coe.int/15th-national-report-from-estonia/1680779ff7 (access: 17 June 2020).

${ }^{22}$ During 2013-2016 the Swedish Discrimination Ombudsman (DO) received 117 complaints about sexual harassment in working life. The vast majority of these (99) complaints were submitted by women. Most of the cases concern young women having been subjected to sexual harassment by a male superior at the workplace: $17^{\text {th }}$ Report by Sweden on the Implementation of the ESC, 24 October 2017, RAP/RCha/ SWE/17(2018), p. 19, https://rm.coe.int/17th-report-from-the-government-of-sweden/168077e399 (acces: 17 June 2020).

${ }^{23}$ On 1 January 2018, new legislation came into force in Iceland prohibiting gender wage gaps. It is now illegal to pay men more than women in firms employing at least 25 staff (requirement to obtain an official certificate proving their equal pay policy). Non-compliance with this wage parity is punishable by fines.

${ }^{24}$ ECSR, Statement of Interpretation on Article 20 of the 1996 Revised European Social Charter/Article 1 of the 1988 Additional Protocol: Equal Pay Comparisons, Conclusions 2012, January 2013. 
In Finland, attention should be drawn to the government's adoption in February 2008 of the "Housing First" programme aimed at reducing long-term homelessness, with the central target of halving homelessness by 2011. The programme achieved the target (Tannio, Fredriksson 2009, p. 199; Pleace 2016, pp. 88-89), ${ }^{25}$ leading the ECSR to note that Finland continued to be committed to tackling homelessness in compliance with Art. $31 \S 2$ of the Social Charter. ${ }^{26}$

In any case, access to housing by young people in vulnerable situations (e.g., migrants, Roma and Travellers) is a complex issue given the wide range of different lifestyles that exist in each country: from this point of view, a recent complaint has been registered on 27 April 2020 (No. 195/2020, European Roma Rights Centre v. Belgium), where the complainant organization denounces that the lack of efforts regarding housing solutions reveals "that the situation has even worsened compared to" the previous decision on the merits of 21 March 2012 (Complaint No. 62/2010, International Federation for Human Rights (FIDH) v. Belgium).

\section{Concluding remarks}

The European Social Charter (alongside the case-law of the European Committee of Social Rights) forms the most striking binding legal source for young people's social rights (Marguénaud, Mouly 2011, p. 685), providing a framework for synergies with both the European Union and the Council of Europe's other instruments and mechanisms in this area.

Local and regional authorities, along with the social partners and civil society organisations (youth sector), play a key part both in disseminating the Social Charter and in implementing it, with a view to helping young people access and exercise the social rights enshrined in it. This crucial role of local and regional authorities in making the Social Charter effective in legal terms (in line with the principle of subsidiarity and the "social" responsibilities that form part of the core of their respective autonomy) should be supported by national, European and international action plans and programmes.

The Social Charter is a vehicle for protecting young people's social rights (as beneficiaries), while also being a platform that benefits from young people's potential active role. Given the values it represents (equality, solidarity, social inclusion, participation), the Social Charter-as the Social Constitution for Europe (Salcedo Beltrán 2018, p. 73)— can benefit from the energy and leadership of young people.

25 The latest figures (2018) show that Finland (5.5 million inhabitants) is the only country in Europe that has succeeded in reducing homelessness year on year. Compared with a total of 18 thousand homeless persons 10 years ago, the figure has fallen to under 7000 , i.e. $0.14 \%$ of the population.

${ }^{26}$ Conclusions 2011, Finland, Art. 31 (right to housing, $\$ 2$-reduction of homelessness). Such conclusion of conformity has been reiterated in Conclusions 2015 and 2019. 
In light of the above, Member States should accept (if they have not yet done so) in the spirit of the "Turin process," ${ }^{27}$ the collective complaints procedure and the revised European Social Charter, since the implementation of the Social Charter and of the case law of the ECSR provide a wide range of good practices concerning access to and the exercise of social rights by young people. To that end, it is also necessary to invest in improving public access to information technologies through existing public services (youth centres, public libraries, media centres, youth information and counselling centres, etc.) in light of the Committee of Ministers' Recommendation CM/Rec(2015)3 on the access of young people from disadvantaged neighbourhood to social rights.

On the other hand, investing in raising awareness of young people's social rights can be done through measures such as celebrations by local or regional authorities of the International Youth Day (12 August) or the European Social Charter Day (18 October). Such "days" can be an opportunity for local and regional authorities to encourage those States which have not yet done so, to accept the 1996 revised Social Charter and the collective complaints procedure so that the Social Charter and its complaints mechanism can serve as awareness-raising vehicles, ensuring that not only public authorities (e.g., welfare services) but also, and above all, young people themselves show greater solidarity and greater engagement in defending their social rights (in particular regarding young people in a more vulnerable situation, e.g., unemployed, migrants or with disabilities, etc.).

Finally, while economic crises are cyclical and may be followed by periods of economic recovery, crises of values can result in a lost generation that is hard to win back (Belorgey 2020).

\section{References}

Belorgey J.M. (2020) Réflexions sur le Coronavirus : bas les masques!, "La Gauche Cactus,” http:// www.la-gauche-cactus.fr/SPIP/spip.php?article2475 (access: 22 June 2020).

Bugeja-Bloch F. (2013) Residential Trajectories of Young French People: The French Generational Gap [in:] R. Forrest, N.-M. Yip (eds.), Young People and Housing: Transitions, Trajectories and Generational Fractures, London - New York.

Bynner J., Parsons S. (2002) Social Exclusion and the Transition from School to Work: The Case of Young People not in Education, Employment, or Training (NEET), "Journal of Vocational Behavior," Vol. 60, Issue 20.

Capitanescu Benetti A., Connac S. (2020) Lécole à l'heure du Covid-19. À quelle vie l'école prépare-t-elle? "Cahiers pédagogiques," Université de Genève, https://archive-ouverte.unige. ch/unige:132658 (access: 23 June 2020).

Guichet C. (2013) Le logement autonome des jeunes, Paris.

${ }^{27} \mathrm{https} / / /$ www.coe.int/en/web/turin-european-social-charter/turin-process (access: 23 June 2020). 
Marguénaud J.P., Mouly J. (2011) Le Comité Européen des Droits Sociaux: un laboratoire d'idées sociales méconnu, "Revue du droit public et de la science politique en France et à l'étranger," No. 3.

O'Kelly K., Muir J. (2016) Taking It Seriously: Guide to Recommendation CM/Rec(2015)3 of the Committee of Ministers of the Council of Europe to Member States on the Access of Young People from Disadvantaged Neighbourhoods to Social Rights, Strasbourg, https://rm.coe.int/ CoERMPublicCommonSearchServices/DisplayDCTMContent?documentId=0900001680 6accfa (access: 16 June 2020).

Pleace N. (2016) Guide sur le logement d'abord en Europe, „Observatoire européen sur le sans-abrisme," https://housingfirsteurope.eu/assets/files/2017/03/HFG_FR_full_digital. pdf (access: 9 June 2020).

Romer D., Jamieson K.H., Pasek J. (2009) Building Social Capital in Young People: The Role of Mass Media and Life Outlook, "Political Communication," Vol. 26, Issue 1.

Salcedo Beltrán C. (2018) Derechos sociales y su garantía: la ineludible aprehensión, disposición e implementación de la Carta Social Europea (Constitución Social de Europa), "Revista de Derecho Social," No. 83.

Sedda F. (2020) Le impreviste rivoluzioni del Covid-19 [in:] A. Guigoni, R. Ferrari (eds.), Pandemia 2020. La vita quotidiana in Italia con il Covid-19, Danyang.

Stangos P. (2016) La protection des droits fondamentaux par le Comité européen des droits sociaux face aux mesures d'austérité imposées par la Grèce, "Semaine sociale Lamy" (Supplément), No. 1746.

Tannio H., Fredriksson P. (2009) The Finnish Homelessness Strategy: From a 'Staircase' Model to a 'Housing First' Approach to Tackling Long-Term Homelessness, "European Journal of Homelessness," Vol. 3.

Toca G. (2018) Universitarios endeudados: una polémica global, “esglobal," https://www.esglobal. org/universitarios-endeudados-una-polemica-global/ (access: 28 August 2018). 